\title{
Target and Non-Target Lepidopteran Pest IPM in Brazil Bt Crop Refuge Areas
}

\author{
Lucas S Barros* \\ Department of Entomology and Acarology, Brazil
}

*Corresponding author: Lucas S Barrosa, Department of Entomology and Acarology,

University of São Paulo, Piracicaba, Brazil.

Received Date: April 18, 2019

Published Date: May 02, 2019

\section{Contextualization}

Among the largest fibers and grains cash crop, Brazil is one of the largest commodity agricultural producer in the world. However, the insect's pest intense attack has limited the Brazilian agricultural crops productivity and sustainability of the main as soybean, corn and cotton [1].

After genetically modified crops expressing insecticidal proteins from Bacillus thuringiensis bacterium (Bt) market released as Integrated Pest Management (IPM) tool, especially for Lepidoptera order pest control, most of growers believed that losses by insect pests damage would be minimized.

In fact, $B t$ has been effective to a target pest group, however the Insect Resistance Management to Bt plants (IRM) has not been implemented and resistance cases came out and technologies failures have been recorded [2,3].

The main IRM strategy have been adopted are Bt plants expressing high dose protein insecticide associated with refuge areas (non- $B t$ plants). However, in most crops field pest resistance cases to $B t$ were connection to low refuge areas adoption [4]. Thus, to ensure field efficacy $B t$ crops requires growing the refuge area and pest management insights [5].

Refuge areas represent a part of the grower's field area where have to be seeded with non- Bt crop with same agronomic characteristics of $B t$ main crop such height and cycle duration. The function of the refuge area is providing susceptible individuals (moths) that may mate with rare resistant insects from $B t$ crop area. This strategy (high dose and refuge) aims to ensure the susceptibility to target pests of $B t$ crop and keep the $B t$ crops efficacy [6].

Seed refuge areas can be done in different layout, such as tracks and borders. In Brazil, it is recommended seed $20 \%$ of soybean and cotton area with non- Bt plants, and $10 \%$ corn. Besides that, the 800 meters maximum distance between $B t$ and non $B t$ areas (structured refuge) is mandatory also [5].

The pest management in refuge areas should be implemented in accordance with the IPM principles, as samplings and monitoring target and non-target pests of Bt crops, natural enemies, and economic threshold (ET) use when necessary for each pest and crop control decision [2].

The fall armyworm, Spodoptera frugiperda is the main target pest of $B t$ corn crop in Brazil. For monitoring this pest in refuge areas, are needed to visually evaluate 5 different plants in 20 representative point in the area. For control decision, it is applied a visual defoliation scale Davis from zero to nine (0-9). In this case, the ET are $20 \%$ of plants with equal note or higher than $3[2,5]$.

In soybean, monitoring and sampling occur by tapping cloth (1.0 x 1.5 meter) and ET adopted in vegetative stage are 10 Spodoptera spp. larvae complex (S. eridania, S.cosmioides and S. frugiperda) for each meter, 4 Heliothinae larvae group (Chloridea virescens and Helicoverpa spp.) for each meter or $30 \%$ of defoliation [2,5].

In reproductive stage, it is recommended to take action when account 10 Spodoptera spp. larvae complex for each meter, 2 Heliothinae larvae group for each meter, or $15 \%$ of defoliation and $10 \%$ attacked pods. Regarding the Anticarsia gemmatalis larvae, Chrysodeixis includens, Rachiplusia nu and Trichoplusia ni (Plusiinae complex), the ET are $30 \%$ of defoliation or 20 larvae for each meter in the vegetative stage and $15 \%$ defoliation or 20 larvae for each meter in reproductive stage [2,5].

Unlike these, in cotton crop it is recommended control measures adoption when detect $15 \%$ of plant pointers attacked with two $C$. virescens larvae for each plant. For Alabama argilacea, 
S. eridania and S. cosmioides, the ET adopted is $10 \%$ defoliation or 2 larvae for each meter until 40 days after plant emergence. After this period, the ET is the same of above cited more $25 \%$ plant pointers defoliation [2].

In terms of $C$. includens in cotton crop, up to 40 days after emergence, the ET are $10 \%$ defoliation or 2 larvae for each meter and $10 \%$ defoliation of plants or 2 larvae for each plant up to this period. Control decision to $C$. virescens and Helicoverpa spp. larves should be done when 6 to $8 \%$ of infested plants with at least one larvae or 5 to 8 larvae in 100 sampled plants.

For $S$. frugiperda, the ET is 6 to $8 \%$ of infested plants with at least one larve, and for Pectinophora gossypiella larvae ET recommendations are to 10 adults caught by pheromone trap in at least 2 nights or until 3 to $5 \%$ attacked squares [2].

Faced the potential lepidopteran pests' infestation and injury by target and non-target pest on Bt crops in refuge areas, the main tool used for the management of these pests has currently been insecticide spray, which should be minimal and when necessary according ET. Insecticides with low toxicity or selective to natural enemies, increases growers' ecological benefits, especially because these benefit insects are mainly responsible for field pest natural mortality $[5,7]$.

An example of this scenario occurs with the egg parasitoids Trichogramma spp. and Telenomus spp., the egg and larvae predators Doru luteipes and Podisus nigrispinus that are not lethaly affected by Diamides and Benzoylureas synthetic insecticides chemical group, as well as microbial Baculovirus insecticide [5,7].

Even though Bacillus thuringiensis (Bt) microbiological insecticide be lepidopterant-pest effective, this kind of pesticide should not be spray in refuge areas in order to not affect IRM strategy [2].

It is important to know that, because there are non- $B t$ plants in growers refuge area, target and non-target $B t$ crop pests may be more intense plant attack. Particularly in tropical countries such Brazil where there is intense crop system season, the IPM and IRM in this scenario has been challenge because polyphagous pests crop like fall armyworm Spodoptera frugiperda, cotton bollworm Helicoverpa armigera and soybean looper Chrysodeixis includens are common and constant attack to Bt crops and non Bt crop [2].

In general, for the growers keep Bt crop technology benefits of for long periods, the seed and correct pest management of refuge is mandatory and the decisions to control the target pests should always be the IPM.

\section{Acknowledgement}

None.

\section{Conflict of Interest}

No conflict of interest.

\section{References}

1. Bernardi O, Bernardi D, Horikoshi RJ, Omoto C, Manejo da Resistência de Insetos a Plantas Bt. Engenheiro Coelho/SP: PROMIP. (2019) IBGE Instituto brasileiro de geografia e estatística. Levantamento sistemático da produção agrícola. PP. 1-95.

2. Omoto C, Bernardi O, Salmeron E, Sorgatto RJ, Dourado PM, et al. (2016) Field-evolved resistance to Cry1Ab maize by Spodoptera frugiperda in Brazil. Pest Management Science 79(2): 1127-1136.

3. Tabashnik BE, Van Rensburg JBJ, Carrière Y (2009) Field-evolved insect resistance to $B t$ crops: definition, theory, and data. J Econ Entomol 102(6): 2011-2025.

4. Tabashnik BE (2008) Delaying insect resistance to transgenic crops. Proc Natl Acad Sci USA 105(49): 19029-19030.

5. (2019) IRAC-BR - Comitê brasileiro de ação a resistência an inseticidas. Recomendações de manejo de resistência a inseticidas e manejo de pragas para soja, algodão e milho no Brasil. pp. 1-40.

6. Tabashnik BE, Brévault T, Carrière Y (2013) Insect resistance to Bt crops: lessons from the first billion acres. Nature biotechnology 31(6): 510 521.

7. Parra JRP, Zucchi RA, Coelho JR A, Geremias LD, Cônsoli FL (2015) Thichogramma as a tool for IPM in Brazil. In: VISON B, Trichogramma in augmentative biological control: A worldwide view of the past, present and future. 